\title{
CLUSTER APPROACH IN ORGANIZATION OF TRANSPORTATION IN THE BALTIC SEA REGION
}

\author{
Olga Nežerenko ${ }^{1,2}$, Ott Koppel ${ }^{3}$, Tarmo Tuisk ${ }^{4}$ \\ ${ }^{1}$ Dept of Business Administration, Tallinn School of Economics and Business Administration, \\ Tallinn University of Technology, Tallinn, Estonia \\ ${ }^{2}$ Estonian Entrepreneurship University of Applied Sciences, Tallinn, Estonia \\ ${ }^{3}$ Dept of Logistics and Transport, Tallinn University of Technology, Tallinn, Estonia \\ ${ }^{4}$ Dept of International Relations, Tallinn School of Economics and Business Administration, \\ Tallinn University of Technology, Tallinn, Estonia
}

Submitted 14 August 2013; resubmitted 16 December 2013, 31 January 2014, 7 June 2014; accepted 17 September 2014; first published online 21 January 2015

\begin{abstract}
The urgency of the issues discussed in this paper stems from the fact that cross-border collaboration is an essential part of commercial transportation today. With the extension of multimodal transportation concept, the efficiency and performance of not only national but also of regional transport systems depend on a synergy which occurs as a result of cooperation between transport enterprises and different modes of transport. The present study analyses the situation of transportation field in the Baltic Sea Region (BSR) in the period 2004-2011. The methodology used is based on Hierarchical Cluster Analysis (HCA), correlation analysis, Bayesian analysis and affinity analysis, which help to identify countries with similar trends in the field of transportation and the common reasons and factors which have led to the emergence of these clusters.
\end{abstract}

Keywords: transportation; cluster analysis; cargo volumes; Baltic Sea Region; infrastructure; co-operation; competition.

\section{Introduction}

The transportation sector has been considered a supporting field of services, which provides trade relations with required infrastructure and means of transport, involving technical, legal and administrative support. While the last global economic crisis in 2008-2009 led to a degradation of economic and trade activities, the transport sector also experienced a significant drop in cargo (and also in passenger) flow.

Moreover, the dependency of the transportation sector on political events and decisions should not be underestimated, especially in the case of the Baltic States the transport activity of which relies on bilateral rather than on multilateral relations with Russia. For the coming years, business activity has taken the course of internationalization.

Amidst one of the most complicated global economic crisis, the business sector (including transportation) faced new challenges. The authors share a view that the new context requires a new way for a strategic approach - namely, a cluster approach.
The urgency of the present paper is confirmed by the following facts:

- the competitiveness of transportation corridors goes beyond the boundaries of a group of enterprises;

- Baltic transportation corridors can be presented as links within an international supply chain;

- cooperation of all transportation chain links (including all modes of transport) allows not only to minimize ecological issues, but also to decrease transportation costs, and promote more rational involvement of transit countries' transport capacities;

- formation of a single regional transportation system would allow the Baltic Sea Region (BSR) to achieve a new quantitative transportation field.

This, in its turn, proves that for the creation of competitive business environment and transportation corridors cooperation between enterprises and the public sector is of great importance (MoEAaC 2011).

Being an essential part of the Trans-European Transport Network (TEN-T), the BSR links East and

Corresponding author: Olga Nežerenko

E-mail: olga.nezerenko@gmail.com 
West, and North and South. Environmental issues, differences in economic development and in infrastructural accessibility, and throughput of the latter in the region require the efficiency of existing BSR transport corridors to increase in order to spread the load on transport infrastructure in the BSR more evenly.

The European Commission (EC) in its White Paper (EC 2011) states that one of the issues that the European Union (EU) has to tackle is a competition on the global transport market. Logistics clusters in the Far East are the main competitors for the European ones. With the extension of multimodal transportation concept, the efficiency of a region's transportation system performance depends on a synergy which occurs as a result of efficient cooperation between countries.

In order to develop the BSR as a gateway for traffic between Asia and Russia, on the one hand, and Europe, on the other, it is vital to develop the present transport network in the BSR and the links to the neighbouring countries, such as Russia, Ukraine, and Belarus. The condition of the network varies in different parts of the region and in the neighbouring countries and calls for special attention to reduce the bottlenecks and develop the vital parts of the network into an agreeable standard that could handle future transport volumes in a satisfactory manner.

Support from all levels - trans-national, national, regional and local level - is needed in order to ensure that the development goes in the set direction of establishing an efficient and smoothly functioning network of infrastructure, whereby all modes of transport are utilized each within their best capacity. According to the foresights, the future of freight corridors depends on politics - and the political agenda in China, Kazakhstan and Russia will set the rules. Eastern Europe will continue to grow and thereby consume and produce more. The flows will depend on the market (TransBaltic 2010).

The aim of the present paper is to analyse the current situation of the field of transportation in the BSR by means of Hierarchical Cluster Analysis (HCA) and to identify reasons and factors contributing to the formation clusters of countries with similar trends in the field of transportation.

The hypothesis of the study is the following: dynamics and responsiveness of country's transport performance during the period from 2004 to 2011 as modelled by HCA will enable to predict the country's recovery from the crisis. Each of the three fields of transportation - rail, sea and road - will be individually tested and managed with negative results of Economic Crisis in Europe.

The geographical coverage of the study complies with the definition of the BSR given by the EC (EC 2009). The BSR consists of eight European countries and one non-European country: Denmark, Estonia, Finland, Germany, Latvia, Lithuania, Poland, Sweden and Norway.

\section{Previous Studies}

The presence of clusters, that is, regional agglomerations of companies and other institutions in industries connected through different types of linkages and spillovers, are associated with higher levels of overall regional economic performance in the Baltic Sea Macro-Region of the EU (Ketels et al. 2012). The reasons for clustering grow directly out of the determinants of national advantage and are a manifestation of their systemic character (Porter 2011).

Garanti and Zvirbule-Berzina (2013) have explored in their paper benefits of regional cluster initiatives at micro (enterprise) and macro (region) a levels and presented the theoretical framework of regional cluster effect on regions' growth and development (Fig. 1).

The researchers conclude that the regional cluster presence has a positive impact on the growth and development of the region.

The urgency of this fact is especially high in terms of variable nature of the world economic system. Authors are of the opinion that development of the BSR transportation field can be achieved by creating a single regional transport cluster. As a result, an increase in efficiency and in a level of business formations, activation of innovation in the field would create a favourable environment for the business sector and activate economic growth and development in the BSR.

Review of the literature shows that the number of research papers investigating the influence of the global economic and financial crisis on different modes of transport is limited. Grama (2011) in her study examines developments of the liner shipping market and freight rates in 2009 and 2010 and concludes that the impact of

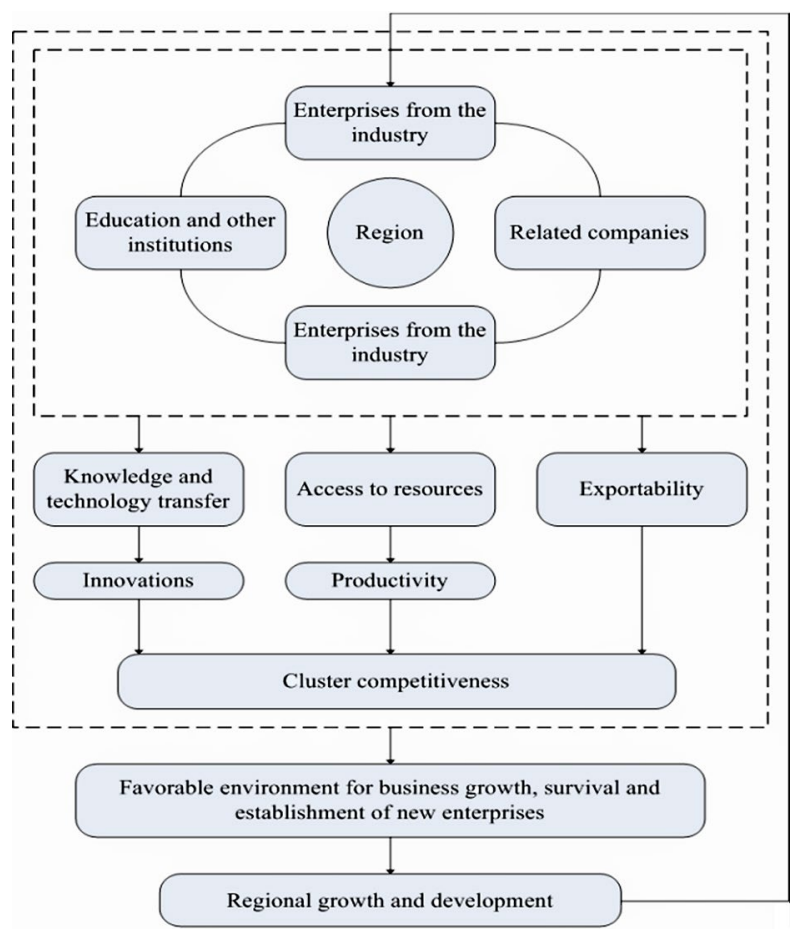

Fig. 1. Regional Cluster Effect on Regional Growth and Development (Garanti, Zvirbule-Berzina 2013) 
the crisis on freight rates was very dramatic - prices for vessels declined by $50-70 \%$ compared to the year 2008 . Decline in demand forced ship-owners to adopt a number of measures, such as cutting the size of their fleet by returning unwanted chartered tonnage to ship-owners, sending some ships to demolition and laying up others.

Development of rail passengers and freight transportation in the EU in the period of 2006-2009 is the focus of the paper by Bălan, G.-S. and Bălan, M. (2010). The authors express the view that railway transport presents less risk factors than other modes of transport, but at the same time their analysis shows that decline in rail freight transportation in 2009 was more significant in Central and Eastern Europe (24\%), where revenue loss has been more severe compared to the Western Europe, and in contrast with other modes of transport, tonnekilometres were already declining in early 2008 and the financial situation of rail companies has been critical for years. As a consequence, some railways in Eastern Europe have been unable to pay their staff in full, suppliers are not being paid and are charging penalties.

The study of Wiskulski and Bar-Kołelis (2012) examines the BSR's tourism potential on the basis of statistics of eight EU countries in 2000-2009 and prospects for 2010-2011. The pattern of factors influencing the transportation of passengers and freight is different. But some, such as expansion of low-cost airlines, economic crisis, increase of operating costs, the 2004 EU Enlargement, growth in fuel prices, historically well-developed connections between certain countries are valid for the freight transport market.

The problem of cooperation between different modes of transport was discussed at length by Rigas et al. (2011). Authors attempted to identify the circumstances under which air and maritime transport could develop a competitive relationship. Authors point out that a new operational environment led to market consolidation, though the condition of either markets can be regarded as fluid and under transition, and its final form will depend on the intensity and the duration of the crisis, which can even lead to oligopoly or even monopoly.

The works published by Guerrero and Rodrigue (2014) look at economic cycles as components of the derived demand of containerized maritime transport at the global level with the usage of cluster analysis, shiftshare analysis and technical analysis. The researchers have expressed the view that future expectations about the growth of containerization need to be assessed within an economic cycle perspective instead of the rather linear perspectives in which containerization is generally considered.

Based on the analysis of literature on the subject it could be argued that there is a very wide range of factors influencing the development processes of transportation field. The conceptual relation between these factors (Brodin 2003) has been identified in Fig. 2.

It is not possible to cover in detail some factors, especially 'qualitative factors' such as political ones, mainly because political processes can be interpreted in various

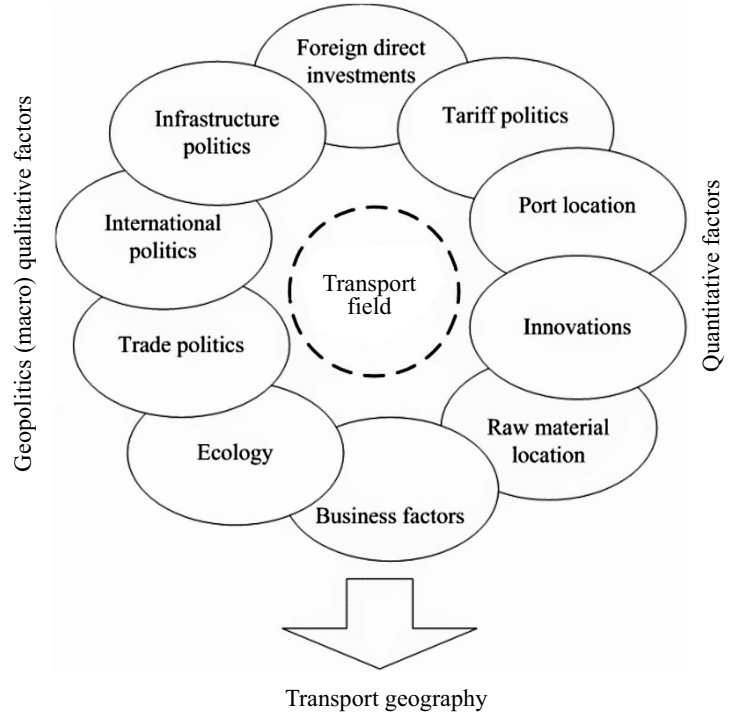

Fig. 2. Conceptual relation between factors influencing the analysis of a field of transportation (Brodin 2003)

ways. Transported cargo volumes, international trade volumes, development level and capacity of transport infrastructure, investments and business activities are the quantitative factors that have been more frequently analysed in research papers.

Taking into account that transportation field is on the edge of economics and politics, there is a continuous interaction between all the above-mentioned factors. As a result of political decisions, such as not allocating additional funding to state railways, and thus, possibly, increasing railway efficiency, the competitiveness among national ports may be indirectly decreased (Brodin 2003).

Both groups of factors also interact with each other. Thus the imposition of protectionist infrastructure tariffs, trade barriers and administrative obstacles may limit the business activity in a sector and have a negative influence on the competitiveness of the whole transport corridor.

International projects in the field of transport on regional level may increase business activity. Within the BSR, cooperation in or implementation of international projects implies the participation of the third countries, which are the suppliers of cargos - in the given case this primarily concerns Russia and China.

\section{Methodology}

The methodology applied in analysing the BSR transport sector in 2004-2011 makes use of four types of analysis:

1. HCA, using Ward's method as a criterion that minimizes the total within-cluster variance;

2. Correlation analysis;

3. Bayesian analysis carried out using B-course, the web-based tool for Bayesian data processing;

4. Affinity analysis carried out using Weka - data mining software (Hall et al. 2009). 
HCA is the main tool for analysing the BSR transport activity within the scope of this paper. There are two main types of empirical studies which can be carried out using the HCA. One type simulates clusters in data of a particular type and then assesses the characteristics and recovery of clusters. The first is based on real data from a particular subject matter, the criterion in the second usually being the interpretability of clusters.

Examples of former researches include a review by Milligan (1981) and a study reported by Milligan and Cooper (1987). The latter concluded that Ward's method performed very well when the data contained clusters with approximately the same numbers of points, but poorly when the clusters were of different sizes.

Cunningham and Ogilvie (1972) and Blashfield (1976) also concluded that for clusters with equal numbers of points Ward's method is successful (Everitt et al. 2011). In addition to the HCA, other statistical data and indices provided by Eurostat (2013) and OECD (2013) will be used in the discussion part (Appendixes 1 and 2). Despite the fact that only the northern part of Germany is officially included in the BSR, statistical data used for HCA covers the whole country. Ward's method allows forming clusters on the basis of cargo flow dynamics, not on the basis of absolute values (i.e. Z-scores of the real values were used within the HCA).

HCA is a statistical method commonly used for finding relatively homogeneous clusters of observations based on their measured attributes. From a dataset, HCA finds groups (clusters) that minimize their endogenous dissimilarity according to a set number of groups. Initially it places each observation in a separate cluster and then combines the clusters sequentially, reducing the number of clusters at each step until only one cluster is left. When there are $\mathrm{N}$ cases, this involves $\mathrm{N}-1$ clustering steps (Guerrero, Rodrigue 2014). Hierarchical classifications may be presented in a two-dimensional diagram, known as a dendrogram, which illustrates the fusions or divisions made at each stage of the analysis (Everitt et al. 2011).

Cluster analysis has limited application in papers on transportation research and it has mainly been used in maritime sector to classify ports according to their function and performance level (e.g. Tongzon 1995). The main idea of cluster approach in the organization of transport activities at a macro-regional level consists in the increasing of efficiency of transportation process due to the links between identified clusters. On the basis of statistical data (cargo volumes) and observed cargo turnover dynamics in the course of eight years (2004-2011) it is possible to see which countries form single clusters. Each country's 'conduct' and its belonging to the cluster allow to forecast the given country's or cluster's recovery after global economic crisis. The latter event has a role of the intervention variable within the current study. Besides, we have empirical data reflecting also the situation during the crisis period.

The following three methods of analysis are carried out with the purpose of explaining changes in cargo volumes across 8 years for the 9 countries and determine factors that influence cargo volumes in the BSR. Ten factors were tested: Gross Domestic Product (GDP) at market prices; export volumes; import volumes; production change in industry; population; investments in road infrastructure; investments in rail infrastructure; investments in port infrastructure; gross value added in trade, communication and transport services and rail infrastructure density. The sample for analysis was 72 country-years as cases.

\section{Results of Empirical Research - the BSR Countries' Performance According to Modes of Transport}

\subsection{Rail Transport}

During the pre-crisis period, in 2004-2007, and the post-crisis period, in 2010-2011 (Figs 3 and 4), Denmark, Norway and Finland (who form the first cluster) seem to demonstrate similarity in dynamics of their performance.

Estonia, Sweden, Lithuania, Latvia with Poland form the second cluster within the hierarchy of railway transport clusters. The most dissimilar country within the region in 2004-2011 is Germany.

There had been changes in the clusters' structure during the crisis period in 2008-2009 (Fig. 4). Estonia and Sweden left their initial cluster and joined the group of Nordic countries - Denmark, Norway and Finland.

That was the reason for Latvia, Lithuania and Poland to lose $21-40 \%$ of cargo turnover.

All the rest of countries showed less significant drop (10-20\%), with the exception of Estonia and Sweden - these countries even increased their performance by $20 \%$ and $1 \%$, respectively.

Despite the fact that Fig. 5 demonstrates that in the post-crisis period participants of clusters remain the same, HCA shows that economic recovery has reduced the step of cluster formation at the second stage - dissimilarity between the two biggest clusters in cargo turnover dynamics has been reduced.

In the period 2010-2011, Latvia and Lithuania demonstrated in their cargo turnover growth by $63 \%$ and 16\%, respectively. Meanwhile Estonia and Sweden showed negative dynamics. Within the second cluster, the countries' turnover dynamics varied.

Sweden lost 3.6\% of cargo turnover, Norway's absolute values remained stable, and Finland had a drop of $9 \%$. Germany, in the post-crisis period, improved its railway performance by $2.9 \%$. It is interesting to note that in the post-crisis period the biggest increase in cargo turnover by railway was demonstrated by the countries whose economies in the crisis period were significantly weakened - Latvia and Lithuania.

Estonia's performance had already dropped during the pre-crisis period as a result of political events, e.g. the Bronze Night of 2007 (Koppel 2008) and followed by blocking of oil products and coal transit flow by railway through Estonian ports. Starting from 2008, international cargo flow in Estonia had demonstrated relatively minor fluctuations despite the economic crisis. 


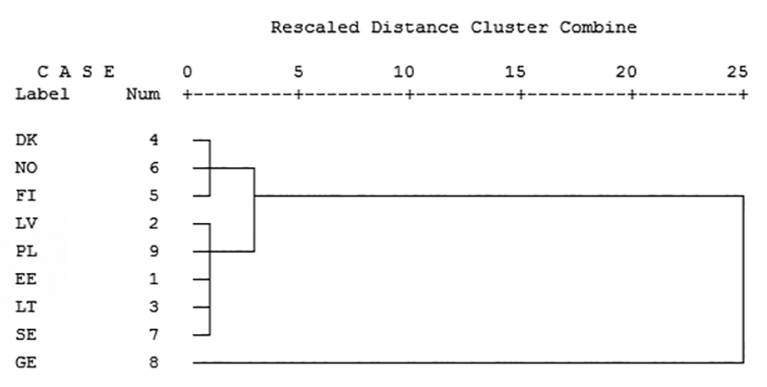

Fig. 3. Dendrogram representing the formation of countries' clusters based on their railway transport flows during 2004-2007

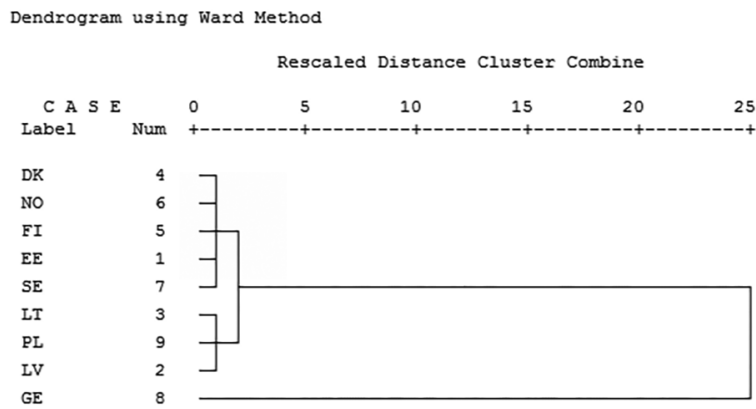

Fig. 4. Dendrogram representing the formation of countries' clusters based on their railway transport flows during 2008-2009

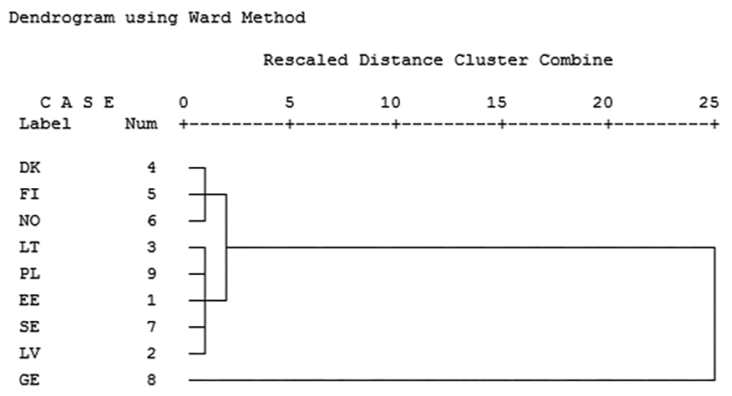

Fig. 5. Dendrogram representing the formation of countries' clusters based on their railway transport flows during 2010-2011

Bălan, G.-S. and Bălan, M. (2010) state that the financial situation of rail companies in Eastern Europe has been critical for years and many rail companies have been hit hard in the economic crisis and are expected to take longer than other modes of transport to recover. The researchers stress the fact that many rail and infrastructure companies in Central and Eastern Europe are chronically underfinanced. Public sector contributions to expenditure in rail infrastructure have been insufficient to allow infrastructure managers to meet the costs of maintenance and renewal, and rail operators are not sufficiently compensated for public service obligations.

Denmark, Finland and Norway form a single cluster in all the three periods. On their example it is possible to highlight the importance of a country's geographical position within a region. From this perspective the share of international rail freight transport in the abovementioned countries is low and on the contrary - Germany, Sweden, Poland and the Baltic States are located in the key international transport corridors.

\subsection{Maritime Transport}

In the very first stage of all the analysed periods, three clusters were formed:

- the cluster of Denmark and Finland;

- the cluster of Estonia, Poland, Latvia and Lithuania;

- the cluster of Norway and Sweden, while Germany remains stand-alone (Fig. 6).

In few clustering stages it is possible to notice the emergence of two larger clusters, while the step of their formation in the pre-crisis and the crisis period remains the same (Fig. 7).

The first cluster encompasses all southern Baltic countries, Denmark, Finland and Poland, and the latter includes Sweden, Norway and Germany.

This clustering result is based largely on two different groups in terms of total sea cargo throughput. Up to 2004 Estonia, Latvia, Lithuania and Poland used to be the main transit corridor for cargo flow from East to West and from West to East.

Important geopolitical changes for this region took place in 2004 when the countries joined the EU, and the position of Baltic ports was transformed from 'former' Soviet to European ones. Baltic Ports became a good and perspective object for Foreign Direct Investments (FDI). But their relatively narrow specialization and dependency on Russian cargo decreased their competitiveness on the international market.

Potential risks for the countries whose port sectors significantly depend on Russia have been discussed in

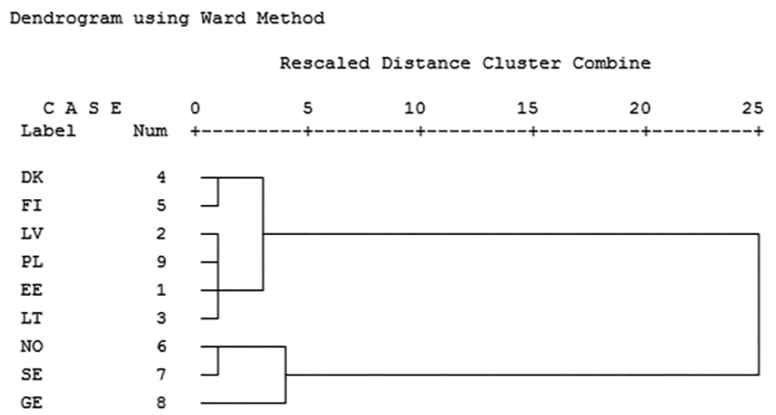

Fig. 6. Dendrogram representing the formation of countries' clusters based on their maritime transport flows during 2004-2007

Dendrogram using Ward Method

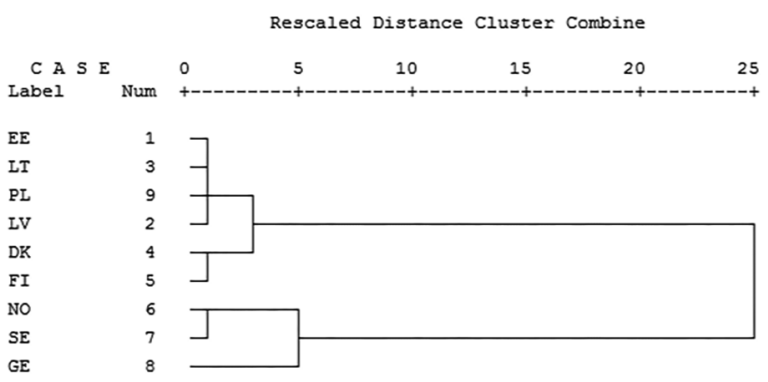

Fig. 7. Dendrogram representing the formation of countries' clusters based on their maritime transport flows during 2008-2009 
a studies by Kirch et al. (2011) and Rijkure and Sare (2013). The first one of abovementioned studies presents three negative scenarios: the first points out the direction of Russian transit flow, which usually depends on bilateral political relations between Russia and each Baltic State. Rijkure and Sare (2013) stress that Latvia managed to attract considerable amounts of Russian cargos to its transit corridor in time of unfavourable relations between Estonia and Russia. The second scenario suggested by Kirch et al. (2011) could be witnessed in 2012, when cargo flow was redirected from European Baltic ports to Russian terminals at the Baltic Sea. And the latter takes into account the increasing role of existing custom union between Russia, Kazakhstan and Belarus. Rijkure and Sare (2013) point out the need to expand the cooperation with Russia and the countries of the Commonwealth of Independent States (CIS) and Central Asia in order to develop the sector of continental shipment.

The tendency of recent years suggests that average vessel size is increasing (Ducruet, Notteboom 2012), and the countries offering deep-sea service are more active in the market's new condition. Fig. 8 demonstrates, as was the case in rail transport, that in the post-crisis period clusters' compositions remained the same.

HCA shows that economic recovery has reduced the rate of cluster formation in the second stage, which means that dissimilarity between Latvia, Poland, Estonia and Lithuania on one side, and Denmark and Finland on another has been reduced.

\subsection{Road Transport}

Within the BSR's international road transport sector three clusters were formed in a very early stage of each analysed period. However their structure has not been stable.

In the pre-crisis period (Fig. 9) the first and the biggest cluster consisted of five countries - Finland, Sweden, Norway, Estonia and Latvia. Lithuania, Poland and Denmark formed the second cluster - these countries have a high level of similarity in the dynamics of cargo turnover.

Germany formed a cluster on its own and joined others in the final, third stage.

In the crisis period, Denmark left the cluster of Lithuania and Poland (Fig. 10).

In the post-crisis period, Latvia joined Poland and Lithuania, forming a new cluster (Fig. 11).

Compared to other modes of transport, international road transport is more adaptable to market and economy's changes. As a result, the biggest fluctuations could be observed in road transport during the crisis period. Sweden lost $35 \%$ of its road cargo turnover; Estonia and Latvia $-27 \%$ and $38 \%$, respectively. Within another cluster, Lithuania lost $16 \%$ and Poland 39\%. Despite the fact that the abovementioned countries experienced the biggest drop in their cargo turnover, in the post-crisis period they showed the quickest recovery in this transportation sector.

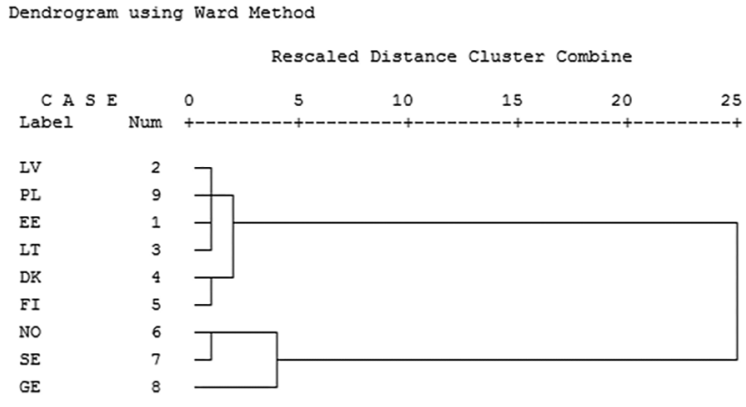

Fig. 8. Dendrogram representing the formation of countries' clusters based on their maritime transport flows during 2010-2011

Dendrogram using Ward Method

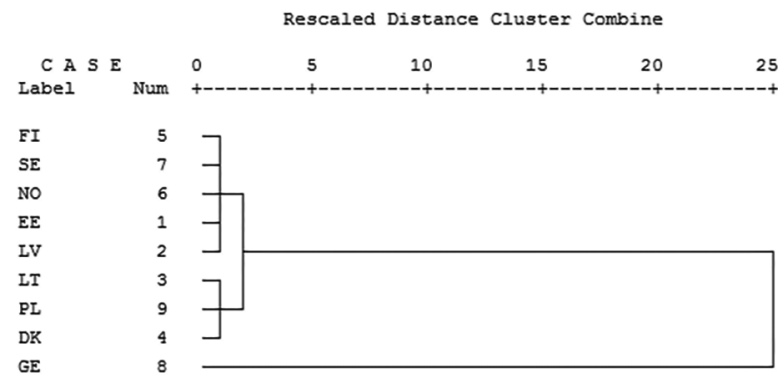

Fig. 9. Dendrogram representing the formation of countries' clusters based on their road transport flow during 2004-2007

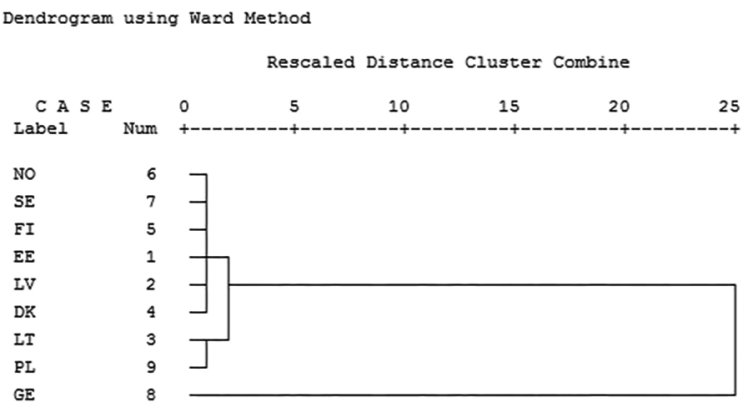

Fig. 10. Dendrogram representing the formation of countries' clusters based on their road transport flow during 2008-2009

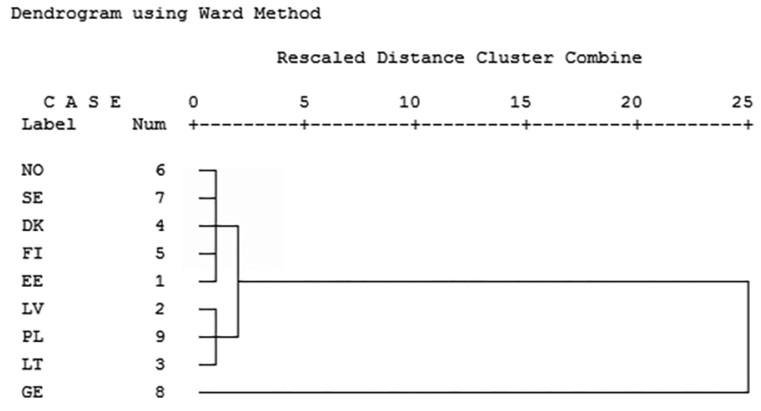

Fig. 11. Dendrogram representing the formation of countries' clusters based on their road transport flow during 2010-2011

Meersman and Van de Voorde (2013) also suggested that the worldwide economic crisis and the Europe's debt crisis have hit road freight more seriously than GDP, and that recovery might bring the road freight in- 
tensities back to pre-crisis levels. At the same time, the issue of border throughput still has to be in a focus. The low throughput of Finnish-Russian and Estonian-Russian borders has an extremely negative impact on the competitiveness of the West-East road corridor. Political factors are making the problem more complicated, and in the case of Estonia the problem is still far from being solved.

HCA gave the authors an opportunity to identify smaller clusters of countries of the BSR which had followed similar patterns in their transportation flows during shorter periods of time from 2004 to 2011. This has enabled us to understand the reasons and factors which effectively contribute to the formation of such clusters of countries that have similar trends according to modes of transportation. Although these factors vary significantly, most of them are still connected either with transport geography or with politics.

\section{Economic Recovery and Transport Activity of the Region}

\subsection{Analysis of the Development Trends Describing} Relationship between Economy and Transport Sector

There are several main indicators of economic activity which are used to understand the relationship between different sectors of economy and for forecasting a sector's development trends. One of them is GDP - a widely used indicator, a universal but too general one to be used in most of the aggregate freight models because it largely consists of value generated in this sector.

Engel and Wang (2011) demonstrate that in OECD countries both trade flows - import and export - are about three times more volatile than GDP. This finding can be extended to apply to the recent crisis. Levchenko et al. (2010) suggest that imports and exports fell so much relative to GDP because their composition is different from the composition of GDP.

Meersman and Van de Voorde (2013) in their research paper investigate a number of alternatives and prove that GDP is not the best indicator for measuring the relationship between economy and the transport sector, because its composition changed, and is still changing, and as a result the link between freight transport and economic activity itself has been changed. The researchers suggest that manufacturing production index, export performance and import penetration rate are more relevant indicators.

This issue becomes even more urgent in the light of the fact that the BSR, located in the periphery of the economic centre of Europe, depends strongly on foreign trade in goods and needs a well-functioning transport infrastructure for its economic growth (EC 2012).

During the economic crisis national governments traditionally set a goal to increase national export volumes. However, a country's export activity is not only the tool for the country's post-crisis recovery process, but it is also a sector of national economy, which provides the transportation sector with additional potential for growth. Table 1 shows the development of export volumes in the BSR countries.

The dynamics of export volume growth in the precrisis period was more active in the EU's new Member States - Estonia, Latvia, Lithuania and Poland, showing great economic potential, got a perfect impulse for their economic and social developments due to joining the EU. At the same time these countries were hit harder by the economic crisis. Lithuania, Finland and Norway experienced the biggest drop in export volume in the crisis period.

In 2010 Estonia, Latvia and Sweden demonstrated faster recovery (with the average growth of 30\%) not only in export volumes, but also in all transport modes analysed within the paper. Finland, Norway, Germany and Poland had relatively the modest growth in export volumes (15\% in average) and in freight transport.

In October 2013, the EU announced its new priorities in transport policy. In the focus of the EC are TEN$T$ value added projects, which provide environmentally sustainable development of the field of transport. The EC gives preferences to TEN-T international projects. In the case of the BSR, such projects promote the development of transportation corridors, such as Rail Baltica or the Twin-Port development project, on which agreement between the Port of Helsinki and the Port of Tallinn was signed in October 2013.

Table 1. Comparison of export volumes in the BSR countries in 2004-2011, \% to a previous year (Eurostat 2013; OECD 2013)

\begin{tabular}{lccc|cc|ccc}
\hline \multirow{2}{*}{ Country } & \multicolumn{3}{c}{ Pre-crisis } & \multicolumn{3}{c|}{ Crisis } & \multicolumn{2}{c}{ Post-crisis } \\
\cline { 2 - 10 } & $2005 / 2004$ & $2006 / 2005$ & $2007 / 2006$ & $2008 / 2007$ & $2009 / 2008$ & $2010 / 2009$ & $2011 / 2010$ \\
\hline Estonia & 1.30 & 1.24 & 1.04 & 1.05 & 0.76 & 1.34 & 1.37 \\
\hline Latvia & 1.29 & 1.18 & 1.23 & 1.14 & 0.80 & 1.30 & 1.31 \\
\hline Lithuania & 1.27 & 1.18 & 1.11 & 1.29 & 0.73 & 1.32 & 1.28 \\
\hline Denmark & 1.10 & 1.07 & 1.02 & 1.06 & 0.84 & 1.07 & 1.10 \\
\hline Finland & 1.06 & 1.16 & 1.06 & 1.00 & 0.68 & 1.16 & 1.08 \\
\hline Norway & 1.20 & 1.17 & 1.01 & 1.17 & 0.71 & 1.17 & 1.16 \\
\hline Sweden & 1.06 & 1.11 & 1.04 & 1.01 & 0.75 & 1.27 & 1.12 \\
\hline Germany & 1.06 & 1.13 & 1.09 & 1.02 & 0.81 & 1.18 & 1.11 \\
\hline Poland & 1.19 & 1.22 & 1.15 & 1.13 & 0.84 & 1.23 & 1.12 \\
\hline
\end{tabular}




\subsection{Statistical Analysis of Factors Influencing the BSR Cargo Volumes in 2004-2011}

In order to determine factors that have influenced the BSR transport activity, the authors tested 10 independent variables by using correlation analysis, Bayesian analysis and affinity analysis.

The results of analyses proved that there are three main attributes which significantly affected the cargo volume handled in the BSR countries in 2004-2011, namely imports, exports and production change in industry.

A strong correlation between 'GDP' and 'investments' into road and rail infrastructures $(r=0.671$, $p=0.000$ and $r=0.365, p=0.002$, respectively) can be observed, as well as between 'imports' and 'investments' into rail and road infrastructure. The latter two have led to the growth in import and export volume (Appendix 3). The correlation analysis demonstrates that investments into sea port infrastructure did not affect significantly the cargo volume and international trade. Thus, it can be concluded that the level of rail and road infrastructure development has played a more important role in the BSR recovery process by supporting the internal market of the Region in contrast to maritime infrastructure. As far as a port sector is concerned, it is known that investments are made with a long-term perspective and finding steady cargo flow for a brand new terminal may prove complicated.

Within B-course web-based Bayesian data processing environment the dependency modelling of joint probability distribution (Myllymäki et al. 2002) was carried out. The resulting model consisted of 6 variables out of 11, with 5 indicators not included in the model (Fig. 12).

The obtained model can be considered as suitable for validating the interconnectedness of the variables. For the sake of clarity, omitted variables are not presented in Fig. 12. At the same time, output of the Bayesian analysis reveals that the dependencies between 'imports' and 'GDP' and between 'imports' and 'exports' are extremely significant.

Naïve causal model, built as a result of dependency modelling, is considered less realistic because there are no latent variables in the domain that causes the dependencies between variables (Fig. 13).

Although in Bayesian 'naïve model' the directed arcs signify causal influence, the model also demonstrates that there are latent variables outside the model, influencing simultaneously through 'changes in production' and 'investments in road infrastructure' also 'imports'. The latter has a direct causal impact on 'cargo volumes'.

Bayesian classification modelling was subsequently applied first in order to learn about dependencies between cargo volumes as the dependent variable and all other variables that are considered independent. The resulting model consisted of merely three variables whereas only 'imports' and 'change in industrial production' were used in the model. This finding is validated

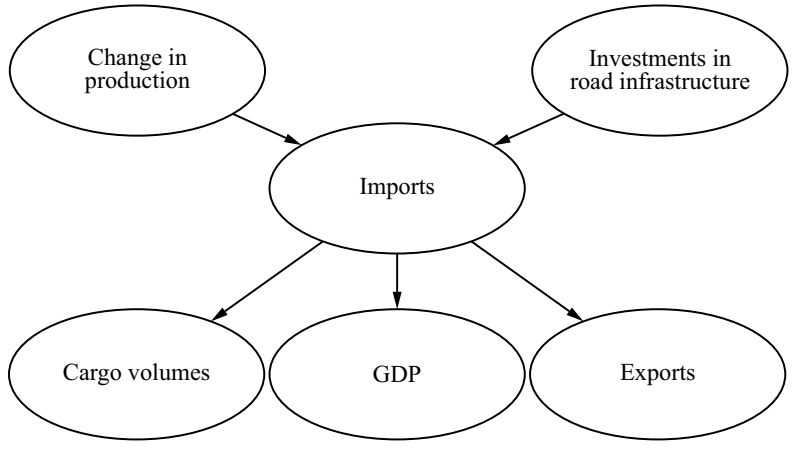

Fig. 12. The Bayesian analysis model proposed for the BSR in the period 2004-2011

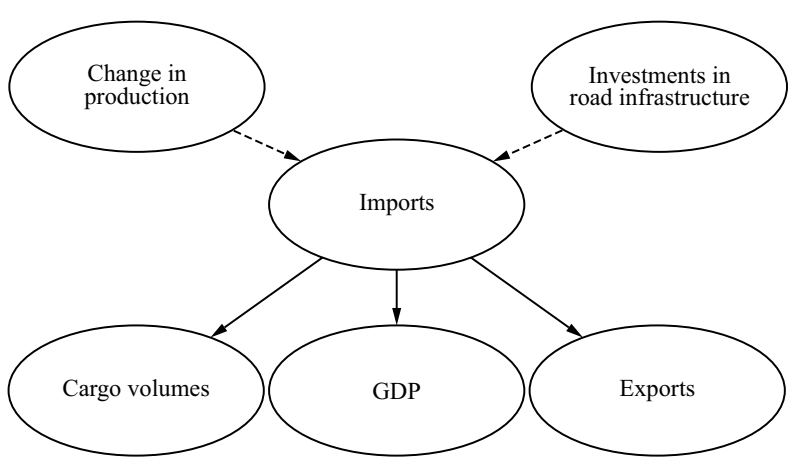

Fig. 13. Naïve casual model for the BSR in the period 2004-2011

by earlier significant correlations between 'cargo volume' and 'imports' $(r=0.495, p=0.000)$ and between 'cargo volume' and 'industrial change' $(r=0.395, p=0.001)$.

The third type of analysis conducted by the authors for testing the dependent variable was the affinity analysis, carried out using the Weka - data mining software (http://www.cs.waikato.ac.nz/ml/weka). The results of this analysis validated the findings by correlation and Bayesian analyses: there are three main associations between the analysed attributes - 'GDP', 'imports', and 'exports'. (That is, association rules found by Weka proved that these three independent variables had the highest (non-probabilistic) frequencies based on the co-occurrences of their changes).

The BSR transport as well as economic potential depends on international trade, production in industry and on sufficient investments in road and rail infrastructure. These three attributes are the strengths of the region which in the light of new EU priorities prepare the ground for a significant jump in its development in the nearest three to ten years.

\section{Discussion}

Business sector has faced various challenges in recent years. Efficient adaptation to market and economy's changes demonstrates a proper business strategy of companies. Despite the fact that politics assigns the development course of transportation sector, business actors' estimations and expectations are vital. 
The World Bank conducts the Logistical Performance Index (LPI) survey every two years to measure on-the-ground trade logistics performance, providing feedback on the logistics 'friendliness' of the countries in which global freight forwarders and express carriers operate and those with which they trade. The LPI reflects the perspective of the global private sector on how countries are globally connected through their main trade gateways (Arvis et al. 2012).

The survey is built up on six logistics issues:

- customs clearance efficiency;

- infrastructure quality;

- the ease of arranging competitively priced shipments;

- the competence and quality of logistics services;

- the ability to track cargo;

- the frequency with which shipments reach the consignee within the scheduled or expected delivery time.

Freight forwarders rate countries on these logistics issues on a scale of 1 (worst) to 5 (best). The overall logistical index represents the qualitative estimation of trade logistics efficiency of a country from the perspective of freight operators (Appendix 4).

In the authors' opinion, a comparison of the transport clusters formed during the post-crisis period and the clusters formed on the basis of the 2012 LPI survey may reveal whether the results of HCA coincide with the assessments of respondents.

The results demonstrate that the formation of transport clusters (based only on cargo turnover dynamics) does not reflect freight forwarders' estimation of a country's supply chain efficiency in cost, time, and reliability (Fig. 14). Estonia, Latvia and Lithuania form a single cluster with a high level of dissimilarity relative to other countries (Fig. 14b). Thus, LPI as an expert's estimation rather demonstrates a possibility to classify countries on the basis of their logistics performance and does not reflect real clusters, which were formed on the basis of cargo flows.

In order to strengthen and improve the efficiency of marine transport and competitiveness of the region, several projects have been launched. MarChain as a pilot program within the StarDust project aims at mapping the content of the national clusters and identifying their current main advantages and the key challenges these clusters are facing (Karvonen, Heikkilä 2013). SmartComp project, carried out in 2012-2013 aimed to unite the maritime clusters of the region and to strengthen existing networks by creating new ones in order to improve competitiveness of the sector and thus enable sustainable growth possibilities for the sector (SmartComp 2013).

Within both projects a number of studies has been conducted - these are aimed to detect differences appearing between clusters, which can either contribute or hinder not only the cluster's competitiveness, but also inter-cluster cooperation in such factors as structure and activity base, innovative capacity, government policy towards clustering, and so on. a)

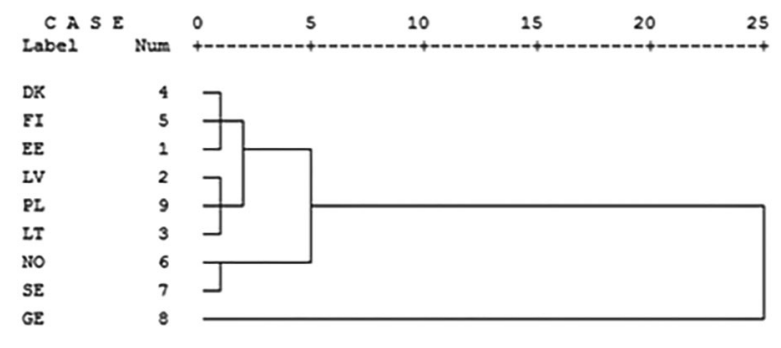

b)

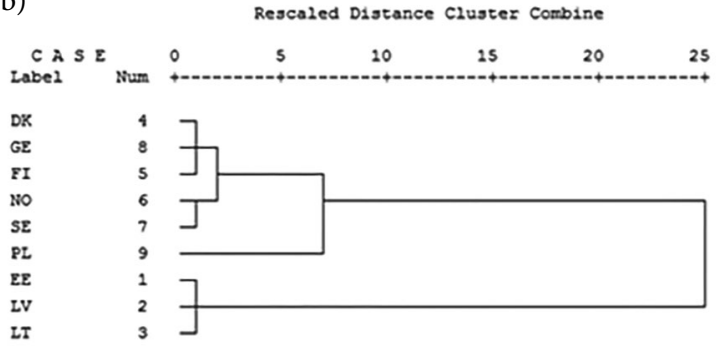

Fig. 14. Dendrograms for the cargo handled in the BSR countries by railway, maritime and road transport in 2012 (a) and LPI 2012 (b)

The transportation process efficiency depends to a higher degree on the Information and Communication Technologies (ICT) sector, in which the BSR has a strong performance. It can been proved by the total share of employment in ICT sectors in the BSR, which is close to $2.7 \%$, compared to $2.6 \%$ in EU-27 and $2.4 \%$ in Europe as a whole, suggesting a slightly higher level of ICT specialisation in the BSR (Sölvell, Protsiv 2013). The existence of this cluster shows that the BSR has a potential for its sustainable growth, because the micro and macro competence is growing. Undoubtedly, the intensity of growth can vary within different fields of economics. Thus, IT field had exhibited relatively intensive development process, and there are other fields which may exhibit more measured or even slow tempos. Each cluster's characteristics are unique in terms of cluster formation and their contribution to economic growth (Sheffi 2013).

ICT, innovation and R\&D sectors' development level varies within BSR clusters. Thus, in accordance with SmartComp (2013) and StarDust (Karvonen, Heikkilä 2013) reports, innovative capacity of Estonia, Finland and Germany can contribute to the creation of a single BSR cluster. Finland's experience may prove, through the involvement of government authorities in the innovation activities, a good example for other BSR countries. The cluster competitiveness and growth potential also depends on the involvement of educational sector. Finland, Sweden, and Germany more actively cooperate with university industry, while Poland's and Lithuania's link of sciences and business as a facilitator in stimulating innovation, knowledge and technology transfer into the business is relatively weak.

At the same time, Estonia and Latvia hinder intercluster cooperation because of their clusters' structure, 
which was formed due to their geopolitical location and transit orientation model, in which the role of large companies is too dominant. As a result, cluster performance depends on the limited amount of enterprises, which can be non-profit ones and in state ownership. As opposed to such structural problems, Finland, Sweden, Lithuania, Poland and Germany are based on diversified structures, which undoubtedly is a facilitating factor contributing to an inter-cluster cooperation (SmartComp 2013; Karvonen, Heikkilä 2013).

Taking into account the specificity of transportation field, there is a complexity in the formation of international supply chain, which would be efficient in terms of ecological, economic and infrastructural issues of the region. Further development approach must be strategic. The results of the research showed that 'natural' clusters have been already formed, thus there is a basis for a single transport cluster formation. Authors suggest that in the nearest future the transport field could be the next one to demonstrate positive tendencies in the formation of the macro-regional transport cluster.

\section{Conclusions}

The application of HCA method enabled the authors to identify homogeneous clusters of the BSR's countries based on the evolution of handled cargo volume by railway, maritime and road transport between 2004 and 2011.

The hypothesis, presented in the study that the dynamics and responsiveness of a country's transport flows during the period 2004-2011 as modelled by HCA, will enable to forecast the country's recovery from the crisis was confirmed. Ten attributes were analysed from the perspective of their influence on transport activity, and the most important of these are the following three: international trade, production in industry and investments in road and rail infrastructure. In addition to economic factors, there are also political events (these can be seen as the 'latent variables') which, while not a focus of this paper, have a great influence on prediction accuracy and on expectations based on quantitative factors.

The results of the analysis could be presented from two perspectives:

1. The first is focused on the level of similarities between the BSR countries. Cluster analysis showed that Germany and Poland had more dissimilarities compared to other BSR countries in all modes of transport. Due to historical and geopolitical aspects, the southern BSR countries' transport field development trends share more similarities. In the authors' opinion, it is necessary to take into account the level of similarity between countries for more efficient implementation of intraregional projects in the field of transportation, because, as a rule, political factors predominate in such decisions.

2. The second is focused on the application level of the cluster approach for the analysis of different transport modes. In the present analysis, clusters were more clearly formed in terms of maritime transport. This is consistent with findings presented in earlier research papers which were mainly concerned with maritime transport.

The authors share the opinion that the present topic has potential for further research that would rely on the results of HCA, as presented in the current study. It is essential to analyse business logistics clusters formed in the field of transportation on a national level and in the BSR.

The BSR has shown a number of ingredients for the evolution of dynamic clusters, but continues to rank relatively low on the level of actual cluster development and within-cluster collaboration. Here also emerges the question about the dominant role of political decisions in the formation of such clusters compared to 'naturally' formed transport environment in the BSR countries. So, the relevance of a long-term forecast is doubtful. Setting time limits would lead to a mid-term period ( $4-5$ years), which does not provide us with precise estimations, considering that the field of transportation most strongly depends on the external environment.

\section{References}

Arvis, J.-F.; Mustra, M. A.; Ojala, L.; Shepherd, B.; Saslavsky, D. 2012.Connecting to Compete 2012. Trade Logistics in the Global Economy. The Logistics Performance Index and its Indicators. The International Bank for Reconstruction and Development / The World Bank. 56 p. Available from Internet: http://siteresources.worldbank.org/TRADE/Resources/239070-1336654966193/LPI_2012_final.pdf

Bălan, G.-S.; Bălan, M. 2010. Economic and financial crisis impact on rail sector, Internal Auditing and Risk Management 3(19): 30-38.

Blashfield, R. K. 1976. Mixture model tests of cluster analysis: accuracy of four agglomerative hierarchical methods, Psychological Bulletin 83(3): 377-388.

http://dx.doi.org/10.1037/0033-2909.83.3.377

Brodin, A. 2003. Baltic Sea Ports and Russian Foreign Trade: Studies in the Economic and Political Geography of Transition. Department of Human and Economic Geography, University of University of Gothenburg. 372 p. Available from Internet: https:/gupea.ub.gu.se/bitstream/2077/2507/1/ gupea_2077_2507_1.pdf

Cunningham, K. M.; Ogilvie, J. C. 1972. Evaluation of hierarchical grouping techniques: a preliminary study, The Computer Journal 15(3): 209-213. http://dx.doi.org/10.1093/comjnl/15.3.209

Ducruet, C.; Notteboom, T. 2012. The worldwide maritime network of container shipping: spatial structure and regional dynamics, Global Networks 12(3): 395-423. http://dx.doi.org/10.1111/j.1471-0374.2011.00355.x

EC. 2012. Communication from the Commission to the European Parliament, the Council, the European Economic and Social Committee and the Committee of the Regions Concerning the European Union Strategy for the Baltic Sea Region. European Commission. Brussels, 23.3.2012. COM(2012) 128 final. 12 p. Available from Internet: http://ec.europa.eu/ regional_policy/sources/docoffic/official/communic/baltic/ com_baltic_2012_en.pdf 
EC. 2011. White Paper: Roadmap to a Single European Transport Area - Towards a Competitive and Resource Efficient Transport System. European Commission. Brussels, 28.3.2011. COM(2011) 144 final. 30 p. Available from Internet: http://eur-lex.europa.eu/LexUriServ/LexUriServ.do ?uri=COM:2011:0144:FIN:EN:PDF

EC. 2009. Communication from the Commission to the European Parliament, the Council, the European Economic and Social Committee and the Committee of the Regions Concerning the European Union Strategy for the Baltic Sea Region. Commission of the European Communities. Brussels, 10.6.2009. $\operatorname{COM}(2009) 248$ final. 11 p. Available from Internet: http://ec.europa.eu/regional_policy/sources/docoffic/official/communic/baltic/com_baltic_en.pdf

Engel, C.; Wang, J. 2011. International trade in durable goods: understanding volatility, cyclicality, and elasticities, Journal of International Economics 83(1): 37-52.

http://dx.doi.org/10.1016/j.jinteco.2010.08.007

Eurostat. 2013. Available from Internet: http://epp.eurostat. ec.europa.eu/portal/page/portal/eurostat/home

Everitt, B. S.; Landau, S.; Leese, M.; Stahl, D. 2011. Cluster Analysis. 5th edition. Wiley. 346 p.

Garanti, Z.; Zvirbule-Berzina, A. 2013. Regional cluster initiatives as a driving force for regional development, European Integration Studies 7: 91-101. http://dx.doi.org/10.5755/j01.eis.0.7.3677

Grama, I. G. 2011. The influence of the global economic crisis on the evolution of liner shipping market, Journal of Academic Research in Economics 3(3): 285-293.

Guerrero, D.; Rodrigue, J.-P. 2014. The waves of containerization: shifts in global maritime transportation, Journal of Transport Geography 34: 151-164. http://dx.doi.org/10.1016/j.jtrangeo.2013.12.003

Hall, M.; Frank, E; Holmes, G.; Pfahringer, B., Reutemann, P.; Witten, I. H. 2009. The WEKA data mining software: an update, SIGKDD Explorations 11(1): 10-18. http://dx.doi.org/10.1145/1656274.1656278

Karvonen, T.; Heikkilä, A. (Eds). 2013. Maritime Clusters in the Baltic Sea Region: Estonia, Finland, Germany, Latvia, Lithuania, Poland and Sweden. StarDust Project. 21 p. Available from Internet: http://www.bsrstars.se/wp-content/uploads/2013/10/Maritime-Clusters-in-the-BalticSea-Region-final.pdf

Ketels, C. H. M.; Hilmola, O.-P.; Weber, R. 2012. The Top of Europe Bracing Itself for Difficult Times: Baltic Sea RegionCollaboration to Sustain Growth. State of the Region Report 2012. Copenhagen, Denmark. 156 p. Available from Internet: http://www.bsr2012.eu/wp-content/uploads/ BDF_SoRR_2012.pdf

Kirch, A.; Nezerenko, O.; Mezentsev, V. 2011. Estonia and other countries of the Baltic Sea region as actors of development: conceptual approach, European Integration Studies 5: 199-204. http://dx.doi.org/10.5755/j01.eis.0.5.1097

Koppel, O. 2008. Impact of Russian hidden economic sanctions on Estonian railway transport, Discussions on Estonian economic policy: Theory and Practice of Economic Policy 16: 26-30.

Levchenko, A. A.; Lewis, L. T.; Tesar, L. L. 2010. The collapse of international trade during the 2008-09 crisis: in search of the smoking gun, IMF Economic Review 58(2): 214-253. http://dx.doi.org/10.1057/imfer.2010.11

Meersman, H.; Van de Voorde, E. 2013. The relationship between economic activity and freight transport, in Ben-Akiva, M.; Meersman, H.; Van de Voorde, E. (Eds.). Freight Transport Modelling, 17-43.
Milligan, G. W. 1981. A Monte Carlo study of thirty internal criterion measures for cluster analysis, Psychometrika 46(2): 187-199. http://dx.doi.org/10.1007/BF02293899

Milligan, G. W.; Cooper, M. C. 1987. Methodology review: clustering methods, Applied Psychological Measurement 11(4): 329-354. http://dx.doi.org/10.1177/014662168701100401

MoEAaC. 2011. Riiklik arengukava "Eesti merenduspoliitika" 2011-2020. Ministry of Economic Affairs and Communications (MoEAaC). Republic of Estonia. 92 p. (in Estonian).

Myllymäki, P.; Silander, T.; Tirri, H.; Uronen, P. 2002. B-course: a web-based tool for Bayesian and causal data analysis, International Journal on Artificial Intelligence Tools 11(3): 369-387. http://dx.doi.org/10.1142/S0218213002000940

OECD. 2013. OECD Factbook 2013: Economic, Environmental and Social Statistics. $235 \mathrm{p}$.

http://dx.doi.org/10.1787/factbook-2013-en

Porter, M. E. 2011. Competitive Advantage of Nations: Creating and Sustaining Superior Performance. Free Press. 896 p.

Rigas, K.; Sambracos, E.; Gatzoli, A. 2011. Air and sea transport: competition strategies under normal and economic crisis environments, SPOUDAI - Journal of Economics and Business 61(3-4): 65-84.

Rijkure, A.; Sare, I. 2013. The role of Latvian ports within Baltic Sea region, European Integration Studies 7: 110-117. http://dx.doi.org/10.5755/j01.eis.0.7.5145

Sheff, Y. 2013. Logistics-intensive clusters: global competitiveness and regional growth, International Series in Operations Research \& Management Science 181: 463-500. http://dx.doi.org/10.1007/978-1-4419-6132-7_19

SmartComp. 2013. Conclusions on Increasing Smart Competitiveness in the Central Baltic Region. Final SmartComp Research Report. 25 p. Available from Internet: http://www. cb-smartcomp.eu/download.php/dms/smartcomp/project_outputs/smartcomp_for_web.pdf

Sölvell, Ö.; Protsiv, S. 2013. Regional \& Cluster Competitiveness in the Baltic Sea Region. Stockholm School of Economics. 64 p. Available from Internet: http://www.bsrstars.se/wpcontent/uploads/2012/10/Report-Cluster-Observatory.pdf

Tongzon, J. L. 1995. Determinants of port performance and efficiency, Transportation Research Part A: Policy and Practice 29(3): 245-252.

http://dx.doi.org/10.1016/0965-8564(94)00032-6

TransBaltic. 2010. TransBaltic Scenarios and Foresight 2030: Foresight Debates. 49 p. Available from Internet: http:// www.transbaltic.eu/wp-content/uploads/2010/09/Transbaltic-scenarios-and-foresight-2030.pdf

Wiskulski, T.; Bar-Kołelis, D. 2012. Passenger traffic on the Baltic Sea region in years 2000-2011, Revista Română de Geografie Politică - Romanian Review on Political Geography 14(1): 34-44. 


\section{APPENDIX 1}

The BSR Countries' Railway, Maritime and Road Transport Performance, 2004-2011

\begin{tabular}{|c|c|c|c|c|c|c|c|c|}
\hline Country & 2004 & 2005 & 2006 & 2007 & 2008 & 2009 & 2010 & 2011 \\
\hline \multicolumn{9}{|c|}{ Railway transport - tnternational transport of goods [billion tonne-kms] } \\
\hline Estonia & 10.0 & 9.9 & 9.7 & 7.3 & 5.2 & 5.4 & 5.9 & 5.5 \\
\hline Latvia & 16.4 & 17.4 & 14.8 & 16.4 & 17.4 & 14.4 & 12.9 & 21.1 \\
\hline Lithuania & 10.2 & 9.0 & 9.7 & 11.4 & 11.1 & 8.8 & 10.1 & 11.4 \\
\hline Denmark & 1.6 & 1.5 & 1.6 & 1.6 & 1.7 & 1.6 & 2.1 & 2.4 \\
\hline Finland & 2.9 & 3.1 & 3.7 & 2.9 & 3.2 & 2.7 & 2.8 & 2.6 \\
\hline Norway & 0.8 & 0.9 & 0.9 & 0.9 & 0.9 & 0.8 & 0.8 & 0.7 \\
\hline Sweden & 7.7 & 7.6 & 7.4 & 7.6 & 7.1 & 7.2 & 8.6 & 8.4 \\
\hline Germany & 46.5 & 46.9 & 56.5 & 60.8 & 62.4 & 47.0 & 52.8 & 54.3 \\
\hline Poland & 15.5 & 14.0 & 16.1 & 16.9 & 15.7 & 9.6 & 11.7 & 12.9 \\
\hline \multicolumn{9}{|c|}{ Maritime transport [million tonnes] } \\
\hline Estonia & 45 & 47 & 50 & 45 & 36 & 39 & 46 & 48 \\
\hline Latvia & 55 & 60 & 57 & 61 & 61 & 60 & 59 & 67 \\
\hline Lithuania & 26 & 26 & 27 & 29 & 36 & 34 & 38 & 43 \\
\hline Denmark & 100 & 100 & 108 & 110 & 106 & 91 & 87 & 93 \\
\hline Finland & 107 & 100 & 111 & 115 & 115 & 93 & 109 & 115 \\
\hline Norway & 198 & 202 & 197 & 199 & 193 & 183 & 195 & 199 \\
\hline Sweden & 167 & 178 & 181 & 185 & 188 & 162 & 180 & 182 \\
\hline Germany & 272 & 285 & 303 & 315 & 321 & 263 & 276 & 296 \\
\hline Poland & 52 & 55 & 53 & 52 & 49 & 45 & 60 & 58 \\
\hline \multicolumn{9}{|c|}{ Road transport - international transport of goods and cabotage [billion tonne-kms] } \\
\hline Estonia & 4.8 & 5.8 & 6.8 & 8.2 & 6.5 & 4.8 & 4.6 & 5.2 \\
\hline Latvia & 5.0 & 5.8 & 8.2 & 10.2 & 9.8 & 6.1 & 8.0 & 9.0 \\
\hline Lithuania & 10.1 & 13.8 & 15.9 & 17.6 & 17.9 & 15.1 & 17.1 & 19.2 \\
\hline Denmark & 12.6 & 12.2 & 9.8 & 9.2 & 8.8 & 6.9 & 4.4 & 4.1 \\
\hline Finland & 5.0 & 4.0 & 4.3 & 3.9 & 3.4 & 3.4 & 4.4 & 3.1 \\
\hline Norway & 3.0 & 2.9 & 4.1 & 4.0 & 4.0 & 3.2 & 3.4 & 3.1 \\
\hline Sweden & 4.3 & 3.9 & 4.4 & 4.2 & 4.4 & 2.9 & 3.5 & 3.5 \\
\hline Germany & 65.8 & 66.0 & 72.0 & 74.4 & 70.0 & 56.7 & 55.3 & 53.5 \\
\hline Poland & 15.5 & 14.0 & 16.1 & 17.0 & 15.7 & 9.6 & 11.7 & 12.9 \\
\hline
\end{tabular}

\section{APPENDIX 2}

Export Volumes of the BSR Countries, 2004-2011 [Billion Euros]

\begin{tabular}{lccccccccc}
\hline \multicolumn{1}{c}{ Country } & 2004 & 2005 & 2006 & 2007 & 2008 & 2009 & 2010 & 2011 \\
\hline Estonia & 4.7 & 6.2 & 7.7 & 8.0 & 8.4 & 6.4 & 8.7 & 12.0 \\
\hline Latvia & 3.2 & 4.1 & 4.9 & 6.0 & 6.9 & 5.5 & 7.1 & 9.4 \\
\hline Lithuania & 7.4 & 9.4 & 11.2 & 12.5 & 16.0 & 11.8 & 15.6 & 20.1 \\
\hline Denmark & 61.9 & 68.4 & 73.7 & 75.2 & 79.4 & 67.3 & 72.7 & 80.3 \\
\hline Finland & 49.4 & 52.6 & 61.4 & 65.6 & 65.5 & 45.0 & 52.4 & 56.8 \\
\hline Norway & 69.3 & 83.5 & 97.8 & 99.4 & 116.8 & 83.7 & 98.5 & 114.4 \\
\hline Sweden & 99.0 & 105.2 & 117.7 & 123.1 & 124.6 & 93.7 & 119.5 & 134.3 \\
\hline Germany & 731.4 & 780.4 & 882.5 & 964.0 & 983.2 & 803.0 & 949.6 & 1058.0 \\
\hline Poland & 60.3 & 71.8 & 88.2 & 102.2 & 115.8 & 97.8 & 120.4 & 135.5 \\
\hline
\end{tabular}




\section{APPENDIX 3}

Bivariate Correlations (Pearson $R, p$-value), $N=72$ for all Cases

\begin{tabular}{|c|c|c|c|c|c|c|c|c|c|c|}
\hline & cargvol & gdp & $\mathrm{imp}$ & $\exp$ & chg & pop & invrail & invse & invrd & gval \\
\hline cargvol & 1 & & & & & & & & & \\
\hline \multirow[t]{2}{*}{ gdp } & $0.366^{\star *}$ & 1 & & & & & & & & \\
\hline & 0.002 & & & & & & & & & \\
\hline \multirow[t]{2}{*}{ imp } & $0.495^{\star *}$ & $0.908^{\star *}$ & 1 & & & & & & & \\
\hline & 0.000 & 0.000 & & & & & & & & \\
\hline \multirow[t]{2}{*}{$\exp$} & $0.532^{\star *}$ & $0.866^{* *}$ & $0.911^{\star *}$ & 1 & & & & & & \\
\hline & 0.000 & 0.000 & 0.000 & & & & & & & \\
\hline \multirow[t]{2}{*}{ chg } & $0.395^{\star *}$ & 0.093 & 0.231 & $0.295^{\star}$ & 1 & & & & & \\
\hline & 0.001 & 0.439 & 0.051 & 0.012 & & & & & & \\
\hline \multirow[t]{2}{*}{ pop } & -0.197 & 0.038 & -0.011 & -0.117 & -0.035 & 1 & & & & \\
\hline & 0.097 & 0.754 & 0.924 & 0.329 & 0.768 & & & & & \\
\hline \multirow[t]{2}{*}{ invrail } & 0.049 & $0.365^{\star *}$ & $0.341^{\star *}$ & $0.370^{* *}$ & -0.117 & 0.146 & 1 & & & \\
\hline & 0.680 & 0.002 & 0.003 & 0.001 & 0.326 & 0.221 & & & & \\
\hline \multirow[t]{2}{*}{ invsea } & 0.171 & 0.180 & 0.173 & 0.191 & -0.049 & -0.152 & -0.134 & 1 & & \\
\hline & 0.151 & 0.131 & 0.145 & 0.107 & 0.685 & 0.201 & 0.261 & & & \\
\hline \multirow[t]{2}{*}{ invrd } & 0.194 & $0.671^{\star *}$ & $0.652^{\star *}$ & $0.501^{* *}$ & -0.203 & 0.072 & $0.334^{\star *}$ & 0.139 & 1 & \\
\hline & 0.102 & 0.000 & 0.000 & 0.000 & 0.087 & 0.548 & 0.004 & 0.245 & & \\
\hline \multirow[t]{2}{*}{ grval } & 0.216 & $-0.383^{\star *}$ & $-0.297^{\star}$ & $-0.285^{\star}$ & 0.129 & -0.016 & -0.175 & -0.130 & $-0.263^{\star}$ & 1 \\
\hline & 0.068 & 0.001 & 0.011 & 0.015 & 0.281 & 0.891 & 0.141 & 0.275 & 0.026 & \\
\hline \multirow[t]{2}{*}{ railden } & -0.025 & -0.047 & 0.043 & -0.079 & -0.157 & 0.214 & 0.144 & -0.075 & 0.219 & 0.105 \\
\hline & 0.833 & 0.697 & 0.718 & 0.511 & 0.187 & 0.072 & 0.226 & 0.530 & 0.064 & 0.379 \\
\hline
\end{tabular}

Notes: ${ }^{\star}$ Correlation is significant at the 0.05 level (2-tailed); ${ }^{\star \star}$ Correlation is significant at the 0.01 level (2-tailed).

\section{APPENDIX 4}

Logistics Indices of the BSR Countries

\begin{tabular}{llll}
\hline \multicolumn{1}{c}{ Country } & 2007 & 2010 & 2012 \\
\hline Estonia & 2.95 & 3.16 & 2.86 \\
\hline Latvia & 3.02 & 3.25 & 2.78 \\
\hline Lithuania & 2.78 & 3.13 & 2.95 \\
\hline Denmark & 3.86 & 3.85 & 4.02 \\
\hline Finland & 3.82 & 3.89 & 4.05 \\
\hline Norway & 3.81 & 3.93 & 3.68 \\
\hline Sweden & 4.08 & 4.08 & 3.85 \\
\hline Germany & 4.10 & 4.11 & 4.03 \\
\hline Poland & 3.04 & 3.44 & 3.43 \\
\hline
\end{tabular}

